\title{
Liquid graphene oxide binder and modified glass fiber separator for lithium sulfur battery with highly improved cycling performance
}

\author{
Maryam Sadat Kiai*
}

Nano-Science and Nano-Engineering Program, Graduate School of Science, Engineering and Technology, Istanbul Technical University, Istanbul 34469, Turkey

Corresponding author. Dr. Maryam Sadat Kiai

* Email address: maryamskiai@gmail.com

\begin{abstract}
Lithium sulfur (Li-S) batteries with high theoretical energy density $\left(\sim 2.5 \mathrm{kWh} \mathrm{kg}^{-1}\right)$ and high theoretical gravimetric capacity $\left(1672 \mathrm{mAh} \mathrm{g}^{-1}\right)$ have drawn great attention as they are promising candidates for large scale energy storage devices. Unfortunately some technical obstacles hinder the practical application of Li-S batteries such as formation of polysulfide intermediates between cathode and anode as well as the insulating nature of sulfur cathode and other discharge products. Glass fiber separators provide some cavities to withstand the volume change of sulfur during cycling leading to long-term cycling stability. Here, application of polar materials with novel liquid graphene oxide (L-GO) binder rather than the standard polyvinylidene fluoride (PVDF) binder as effective coatings on the glass fiber separator of the Li-S cell have been developed to suppress the shuttle effect. The deposition of silicon dioxide $\left(\mathrm{SiO}_{2}\right)$, titanium dioxide $\left(\mathrm{TiO}_{2}\right)$ and poly (1,5-diaminoanthraquinone) (PDAAQ) with L-GO binder on the glass fiber separator was investigated with polycarboxylate functionalized graphene (PC-FGF/S) cathode and Li metal anode. The cells with modified coatings and L-GO as an efficient binder could accelerate conversion of long-chain polysulfides to short-chain polysulfides and
\end{abstract}


significantly delayed the growth of lithium dendrites resulted the capacity retention of $\sim 1020$, 1070 and $1190 \mathrm{mAh} \mathrm{g}^{-1}$ for the cells with $\mathrm{SiO}_{2} / \mathrm{L}-\mathrm{GO}, \mathrm{TiO}_{2} / \mathrm{L}-\mathrm{GO}$ and PDAAQ/L-GO coated separators after 100 cycles. The results demonstrate that ultrathin $\mathrm{SiO}_{2}, \mathrm{TiO}_{2}$ and PDAAQ containing coatings with L-GO binder on the glass fiber separator can drastically improve the cyclability of the Li-S cells.

Keywords: Li-S batteries, Separator modification, L-GO binder, Cycling stability, Polysulfide dissolution

\section{Introduction}

Rechargeable batteries such as lead-acid, nickel-cadmium, lithium ion and sodium ion batteries have penetrated in the market for over a century with a variety of applications. As the demand for electric vehicles and sustainable portable devices surges, advanced rechargeable batteries must emerge in the market [1]. Li-ion batteries have become noticeable over the past two decades in several portable electronics, owing to their higher energy density compare to other rechargeable batteries [2]. However the theoretical specific energy for conventional Li-ion batteries is only $387 \mathrm{Wh} \mathrm{kg}^{-1}$. Having high theoretical discharge capacity of $1672 \mathrm{mAhg}^{-1}$ with relative nontoxicity, and low operating voltage [3]. Abundance of sulfur make lithium-sulfur (Li-S) batteries a viable choice for the future energy storage applications. Foremost challenge in Li-S batteries is the insulating nature of sulfur. During the conversion reaction, formation of solid discharge products $\left(\mathrm{Li}_{2} \mathrm{~S}_{\mathrm{n}}\right)$ in electrolyte leads to large volume change upon cycling as well as reduction in the cycling stability. During discharge process, reaction of $\mathrm{S}_{8}$ with $\mathrm{Li}^{+}$leads to formation of soluble polysulfides in the electrolyte and subsequently their diffusion toward the 
anode. Diffusion of these active spices causes the shuttle effect, known as the most serious problem for the capacity degradation in the Li-S batteries, which subsequently causing ion mobility inhibition and loss of active material [4-6]. However, to alleviate this problem, significant progress has been achieved in recent years by applying novel coatings on the separator or/and composite cathodes and having novel cell configurations [7-15]. Nanocomposite cathodes have drawn much attention as the most promising materials due to their efficiency, low cost, stability, and high electrical conductivity $[16,17]$. Besides, they also serve as an electron collector and transporter further increasing ion and electron mobility [18]. Glass fiber (GF) membrane is defined as a potential separator for Li-S batteries. Highly porous GF membranes demonstrate high liquid electrolyte uptake and facile ion movement [19]. Recently, efforts have been focused on the further development on glass fiber separator via defining effective coatings including conductive carbonous framework, metal oxides, or conductive polymers [20-28]. Among various coatings, 2D materials such as graphene or GO has been investigated recently to improve cyclic stability and superior interfacial compatibility with the cathode. Graphene could provide a highly electrically conductive network, sturdy mechanical support and high sulfur loading area. GO membranes are able to suppress polysulfide by electrostatic repulsion and steric exclusion in long-term cycling. The typical 2D structure of GO can alleviate the loading amount to form an effective polysulfide shield layer [29-31]. The non-polar or poor polar properties of carbon materials make weak interactions with lithium polysulfides and reduce reutilization of sulfur species. Several polar metal oxides/sulfides e.g., $\mathrm{Al}_{2} \mathrm{O}_{3}, \mathrm{SiO}_{2}, \mathrm{TiO}_{2}, \mathrm{Ti}_{4} \mathrm{O}_{7}, \mathrm{MnO}_{2}$ and $\mathrm{TiS}_{2}$ have been applied to hinder lithium polysulfides diffusion due to the strong interactions between metal and sulfur species [32-38].

Here, we report application of polar materials with GO binder rather than the standard PVDF binder in NMP solvent as an effective coating on the glass fiber separator of the Li-S cell. 
The only known to us example of the use of GO as a binder in Li-S cells exhibited superior electrochemical performance with double side coatings on the glass fiber separator.

The cells with modified coatings and L-GO as an efficient binder could accelerate conversion of long-chain polysulfides to short-chain polysulfides [39].

The presence of GO as a binder in the coatings significantly delayed the growth of lithium dendrites and provided chemical and mechanical stability to the Li-S cell. Herein, we compare the functionality of the various coatings using three different nanomaterials $-\mathrm{SiO}_{2}, \mathrm{TiO}_{2}$ and poly (1,5-diaminoanthraquinone) (PDAAQ) and discuss their advantages for improving the electrochemical performance. We suggest that the PDAAQ structure with double bond oxygen group plays more important role to restrain the migration of polysulfide intermediates toward the anode. Additionally GO as a binder with abundant oxygen containing groups was shown to suppress the polysulfide dissolution. Inclusion of $\mathrm{SiO}_{2}$ and $\mathrm{TiO}_{2}$ within the coatings is also attractive because of their strong chemical bonding formation between $\mathrm{TiO}_{2}$ and $\mathrm{SiO}_{2}$ with lithium polysulfide [40 -45].

\section{Experimental Section}

\subsection{Preparation of sulfur/polycarboxylate functionalized graphene (PC-FGF) cathode}

Sulfur powder ((S, 99.5\%, Sigma-Aldrich)) and poly carboxylate functionalized graphene (PCFGF, Sigma-Aldrich) were mixed at a weight ratio of 7:3 using slurry method in agate mortar. The composite was mixed with polyvinylidene fluoride (PVDF, Solef 5130, Solvay) at a weight ratio of 90:10 and the mixture was dispersed in 1-methyl-2-pyrrolidinone (NMP, Sigma-Aldrich, $\geq 99.5 \%$ purity). The resulting cathode slurry was spread on an aluminum foil ( $20 \mu \mathrm{m}$ thick) using the doctor blade technique, and dried in a vacuum oven at $60^{\circ} \mathrm{C}$ for 12 hours. 
The mass loading of sulfur in the cathode was $\sim 2.5 \mathrm{mg} \mathrm{cm}^{-2}$.

\subsection{Separator preparation (PDAAQ/L-GO)}

A mixture of poly (1,5-diaminoanthraquinone) (PDAAQ, 85\%,148 Mw 238.24 g/mol, SigmaAldrich) and liquid graphene oxide ( $\mathrm{L}-\mathrm{GO}, 4 \mathrm{mg} / \mathrm{mL}$ dispersion in $\mathrm{H}_{2} \mathrm{O}$, Sigma-Aldrich) with a mass ratio of 4:1 was placed in an agate mortar and ground and stirred for 30 minutes. The slurry was then coated on one side of a glass fiber separator (Whatman, Grade GF/C with the thickness of $260 \mu \mathrm{m}$ ) and dried in a vacuum oven at $60^{\circ} \mathrm{C}$ for 12 hours. Highly accurate probe is used for thickness of coating with a measuring range from 0 to $200 \mu \mathrm{m}$. The coating thickness of PDAAQ/L-GO was $43 \mu \mathrm{m}$.

\subsection{Separator preparation $\left(\mathrm{TiO}_{2} / \mathrm{L}-\mathrm{GO}\right)$}

Titanium dioxide nanoparticles $\left(\mathrm{TiO}_{2}\right.$, Rutile nanopowder, $21 \mathrm{~nm}$ particle size, $\geq 99.5 \%$ trace metals basis, Sigma-Aldrich) and L-GO with a mass ratio of 4:1 was placed in an agate mortar and ground and stirred for 30 minutes. The slurry was then coated on one side of a glass fiber separator and dried in a vacuum oven for 12 hours. The coating thickness of $\mathrm{TiO}_{2} / \mathrm{L}-\mathrm{GO}$ was 40 $\mu \mathrm{m}$.

\subsection{Separator preparation $\left(\mathrm{SiO}_{2} / \mathrm{L}-\mathrm{GO}\right)$}

Silicon dioxide nanoparticles $\left(\mathrm{SiO}_{2}, \sim 99 \%, 1-5 \mu \mathrm{m}\right.$ Sigma-Aldrich) and L-GO with a mass ratio of 4:1 was placed in an agate mortar and ground and stirred for 30 minutes. The slurry was then coated on one side of a glass fiber separator and dried in a vacuum oven for 12 hours. The coating thickness of $\mathrm{SiO}_{2} / \mathrm{L}-\mathrm{GO}$ was $38 \mu \mathrm{m}$. 


\subsection{Electrolyte preparation}

$1 \mathrm{M}$ bis (trifluoromethane) sulfonamide lithium (LiTFSI, 99.95\% trace metals basis, SigmaAldrich) and 0.5 M lithium nitrite $\left(\mathrm{LiNO}_{3}, 99.99 \%\right.$ trace metals basis, Sigma-Aldrich) in a solvent mixture of 1,3- dioxolane (DOL, 99\%, Sigma-Aldrich) and 1,2-dimethoxyethane (DME, 99.5\%, Sigma-Aldrich) (1:1) was prepared. Amount of electrolyte in different coin cells was adjusted at $20 \mu \mathrm{L} / \mathrm{mg}$ of $\mathrm{S}$.

\subsection{Electrochemical performance characterization}

The CR2032-type coin cells were assembled with PC-FGF/S composite cathode, coated glass fiber separator, lithium metal anode and electrolyte in an argon-filled glove box. The cells were cycled between 1.5 and $3 \mathrm{~V}$ on a Neware BTS 3008 battery tester at room temperature. The cyclic voltammetry (CV) measurements and electrochemical impedance spectroscopy (EIS) tests were performed by a CHI660E electrochemical workstation with a scan rate of $0.1 \mathrm{mV} \mathrm{s}^{-1}$ in a potential range of 3-1.5 $\mathrm{V}$ (vs. $\mathrm{Li}+/ \mathrm{Li}$ ) and $1 \mathrm{MHz}$ to $1 \mathrm{~Hz}$ at an AC voltage amplitude of 10 $\mathrm{mV}$.

\subsection{Materials characterization}

Surface characterization were carried out using SEM equipped with an EDS. XRD diffraction analysis is carried out with Rigaku smart lab by using filter $\mathrm{Cu}$ Ka radiation $(\mathrm{k}=1.541 \AA)$. Elemental compositions were analyzed using X-ray photoelectron spectroscopy (Hemispherical analyzer, Thermo Scientific K-Alpha XPS). 


\section{Results and discussion}

The configuration of the cell with three different coatings on glass fiber separator is shown in Figure $1 . \mathrm{SiO}_{2}, \mathrm{TiO}_{2}$ and PDAAQ coatings with L-GO binder on the glass fiber separator could trap polysulfides through physical and chemical confinement of polysulfides. Among them, PDAAQ could adsorb more polysulfides on the surface of glass fiber separator due to redoxassisted hydrogen bonding of quinone groups in PDAAQ, simultaneously increasing the specific capacity. $\mathrm{SiO}_{2}$ and $\mathrm{TiO}_{2}$ could adsorb some polysulfide on the surface of the glass fiber separator and non-adsorbed polysulfide can be diffused to the anode, simultaneously decreasing specific capacity.
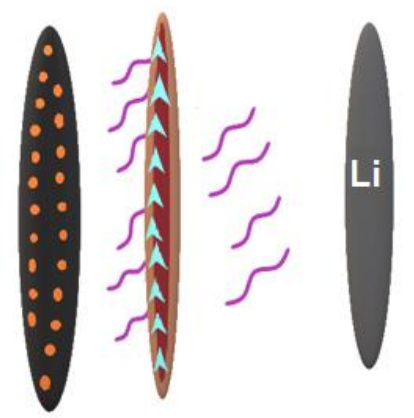

$\mathrm{SiO}_{2}$
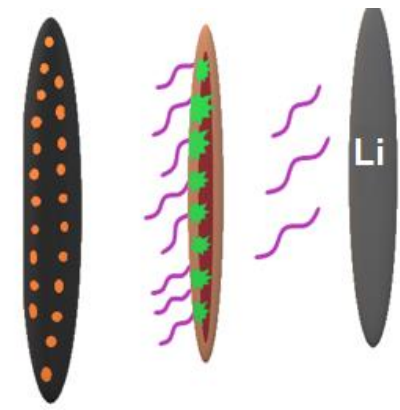

$\mathrm{TiO}_{2}$
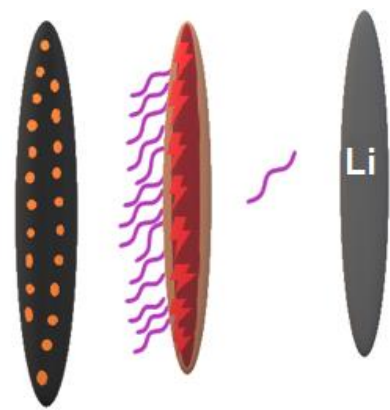

PDAAQ
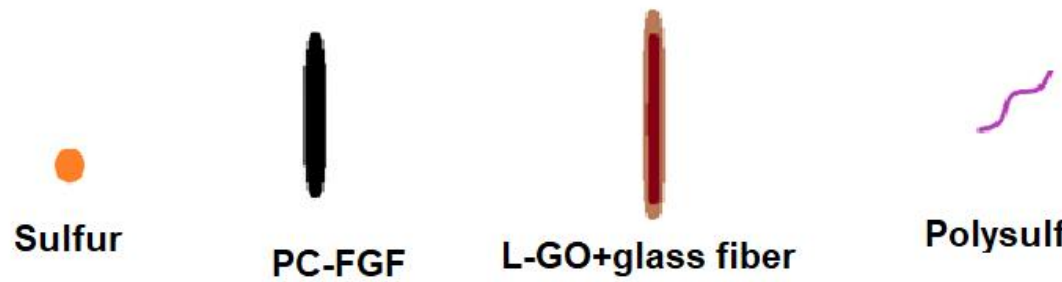

Polysulfides

Figure 1. Schematic for the Li-S batteries configuration consisting of glass fiber separator with $\mathrm{SiO}_{2}, \mathrm{TiO}_{2}$, PDAAQ coating and L-GO binder. 
The deposition of $\mathrm{SiO}_{2}, \mathrm{TiO}_{2}$ and PDAAQ with $\mathrm{L}-\mathrm{GO}$ binder on the glass fiber separator was investigated by the SEM and corresponding EDS analysis (Figure 2). As shown in Figure 2a-c, composites with $\mathrm{SiO}_{2}, \mathrm{TiO}_{2}$ and PDAAQ are uniformly distributed on the surface of the glass fiber separator. Continuous layers was observed for $\mathrm{TiO}_{2} / \mathrm{L}-\mathrm{GO}$ and $\mathrm{SiO}_{2} / \mathrm{L}-\mathrm{GO}$ coated glass fiber separators. It is seen that the use of $\mathrm{TiO}_{2}$ rather than $\mathrm{SiO}_{2}$ resulted in more smooth and homogeneous surface coverage. The tubular geometry of PDAAQ enhanced porous sites to trap polysulfides. Additionally, self-aggregation was hindered by PDAAQ enhanced ionization. Corresponding EDS analysis was conducted for all three coated separators. The EDS images (Figure 2d-f) provide detailed information about elemental spectra and show that peaks were in good agreement with randomly selected area. It demonstrates the presence of $\mathrm{C}, \mathrm{Ti}, \mathrm{Si}, \mathrm{N}$ and $\mathrm{O}$ elements. 

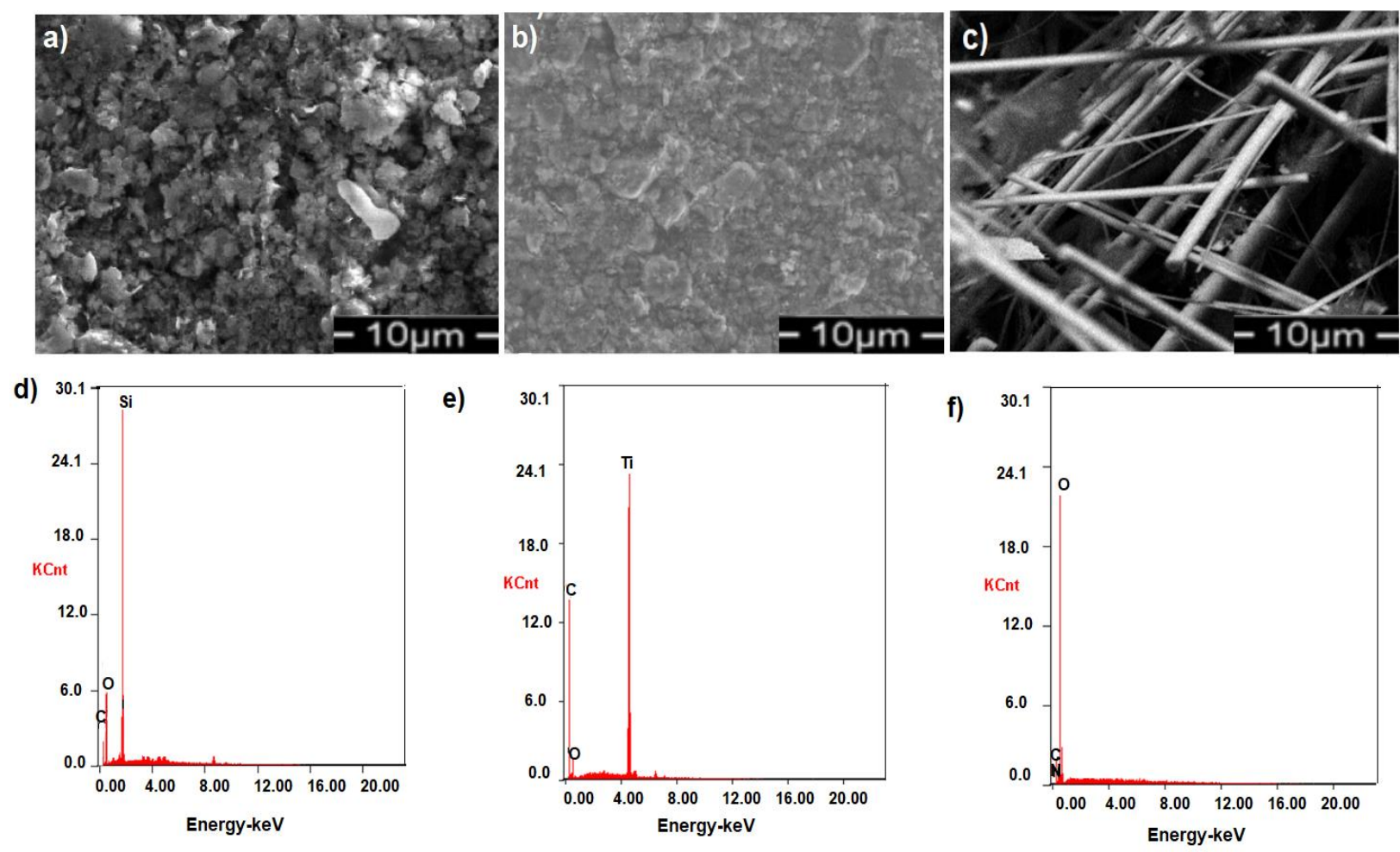

Figure 2. SEM micrographs of a) $\mathrm{SiO}_{2} / \mathrm{L}-\mathrm{GO}$, b) $\mathrm{TiO}_{2} / \mathrm{L}-\mathrm{GO}$ and c) PDAAQ/L-GO coated glass fiber separator; $\mathrm{EDS}$ analysis of d) $\mathrm{SiO}_{2} / \mathrm{L}-\mathrm{GO}$ e) $\mathrm{TiO}_{2} / \mathrm{L}-\mathrm{GO}$ and f) $\mathrm{PDAAQ} / \mathrm{L}-\mathrm{GO}$ coated glass fiber separator.

XRD diffraction pattern is shown in Figure 3. The graphene oxide (GO) peak is observed in all three samples at $2 \theta=13.6^{\circ} . \mathrm{SiO}_{2}$ nanoparticles peaks reveal the formation of particles in $\mathrm{nm}$ range and the reflection from (100), (110), (102), (111) and (220) planes, at $2 \theta$ values $18.86^{\circ}$, $24.55^{\circ}, 35.10^{\circ}, 43.80^{\circ}$ and $64.70^{\circ}$. Rutile $\mathrm{TiO}_{2}$ peak from (110) plane is observed at 25.5 degree diffraction spectra. Other peaks reveal the reflection from (111), (210), (211), (204), (110), (220) and (215) planes at $2 \theta$ values $31.7^{0}, 40.08^{0}, 49.1^{0}, 55.2^{0}, 63.7^{0}, 70.3^{0}$ and $76.06^{0}$.

PDAAQ peak intensity at $2 \theta=17.4^{0}$ corresponding to the (100) diffraction of the hexagonal lattice is overlapped with graphene oxide peak at $2 \theta=13.6^{\circ}$ and one sharp peak is observed. 
Other PDAAQ peak at $2 \theta=25.01^{0}$ corresponding to second-order diffraction of the first peak $[39,46-49]$.

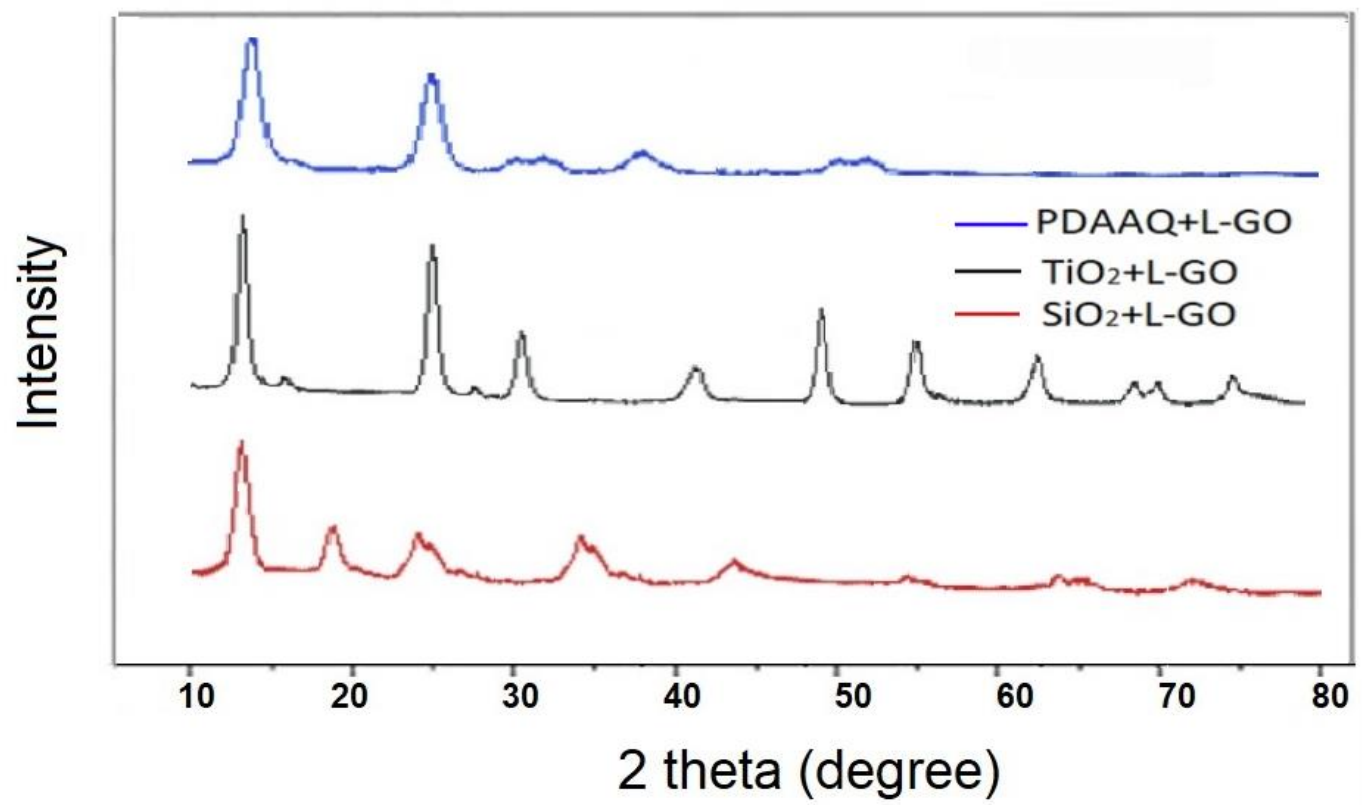

Figure 3. $\mathrm{XRD}$ patterns of $\mathrm{PDAAQ}+\mathrm{L}-\mathrm{GO}, \mathrm{TiO}_{2}+\mathrm{L}-\mathrm{GO}$ and $\mathrm{SiO}_{2}+\mathrm{L}-\mathrm{GO}$ coated glass fiber separator.

The XPS data (Figure 4a) revealed the $\mathrm{SiO}_{2} / \mathrm{L}-\mathrm{GO}$ coated glass fiber separator felt to consist of $\mathrm{O} 1 \mathrm{~s}, \mathrm{C} 1 \mathrm{~s}$ and $\mathrm{Si} 2 \mathrm{p}$ peaks at $534.5,284.1$ and $110.4 \mathrm{eV}$ respectively. The $\mathrm{Si} 2 \mathrm{p}$ spectrum emphasized the chemical state of $\mathrm{Si}$ and in to be $\mathrm{Si}^{+4}$. As seen the XPS spectrum proves that the coated $\mathrm{SiO}_{2} / \mathrm{L}-\mathrm{GO}$ involves $\mathrm{SiO}_{2}$. According to Figure 4 b, for $\mathrm{TiO}_{2} / \mathrm{L}-\mathrm{GO}$ coated glass fiber separator the XPS Ti2p peak centered at about $454.1 \mathrm{eV}$ and the O1s and C1s XPS signal centered at binding energies of 534.5 and $284.1 \mathrm{eV}$ respectively. As seen in Figure 4c, for 
PDAAQ/L-GO coated glass fiber separator the peak at 284.1, 405.8, and $534.5 \mathrm{eV}$ can be assigned to $\mathrm{C} 1 \mathrm{~s}, \mathrm{~N} 1 \mathrm{~s}$, and $\mathrm{O} 1 \mathrm{~s}$, respectively [50-55].
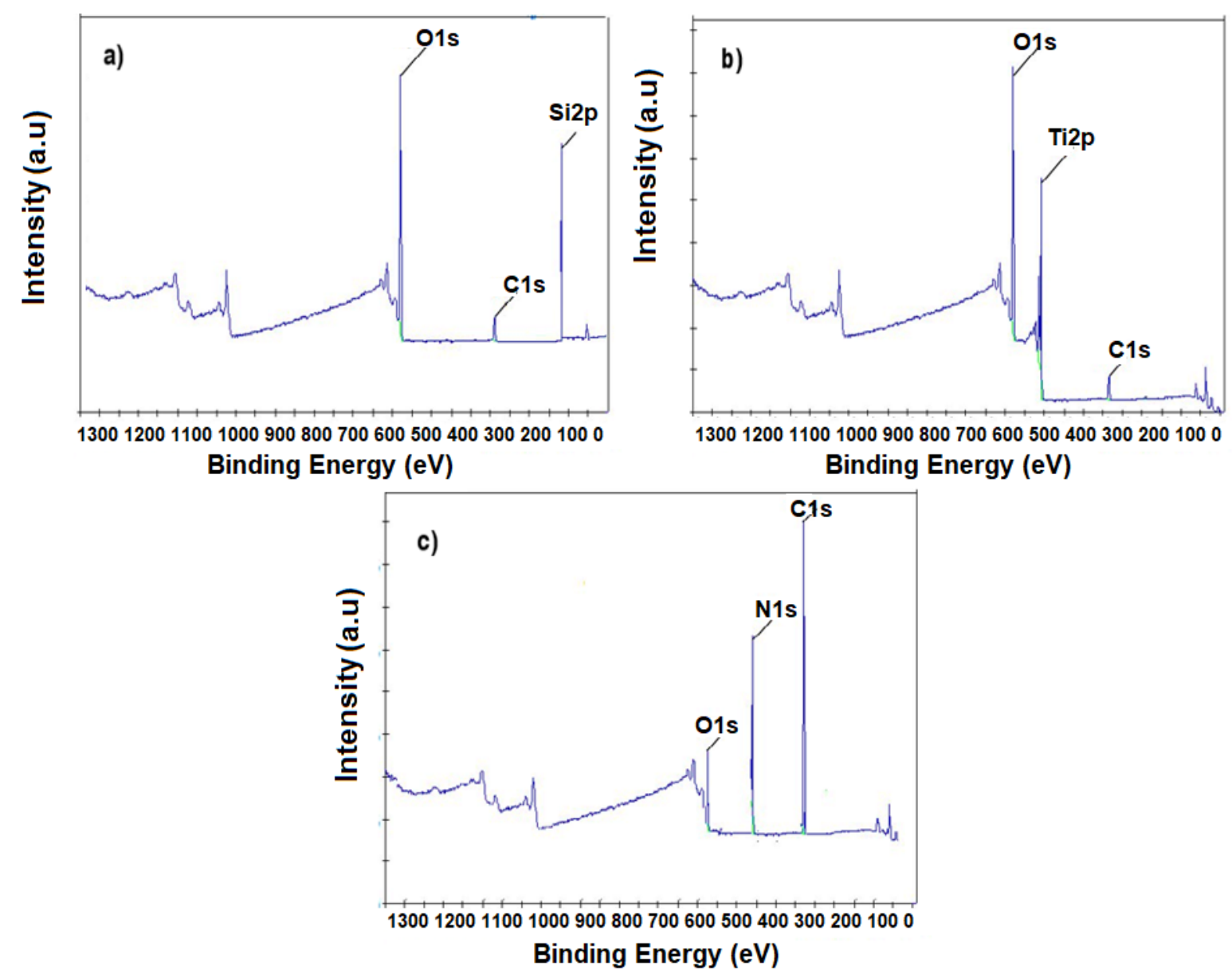

Figure 4. XPS survey spectra of the a) $\mathrm{SiO}_{2} / \mathrm{L}-\mathrm{GO}$ b) $\mathrm{TiO}_{2} / \mathrm{L}-\mathrm{GO}$ c) PDAAQ/L-GO.

To further investigate the effect of $\mathrm{SiO}_{2}, \mathrm{TiO}_{2}$ and PDAAQ coatings with $\mathrm{L}-\mathrm{GO}$ binder on the cell performance, the cycle performance of the Li-S cells with the uncoated and coated glass fiber separators was studied at a $1 \mathrm{C}$ rate in Figure $5(1 \mathrm{C}=1685 \mathrm{mAh})$. The cells with $\mathrm{TiO}_{2} / \mathrm{L}-$ 
GO and PDAAQ/L-GO separators showed increased initial discharge capacities of $\sim 1700 \mathrm{mAh}$ $\mathrm{g}^{-1}$. Moreover, the capacity retention of $\sim 1070$ and $1190 \mathrm{mAh} \mathrm{g}^{-1}$ was observed for the cells with $\mathrm{TiO}_{2} / \mathrm{L}-\mathrm{GO}$ and PDAAQ/L-GO coated separators after 100 cycles. (63-70\%)

The cell with $\mathrm{SiO}_{2} / \mathrm{L}-\mathrm{GO}$ coated separator delivered decreased initial capacity of $\sim 1180 \mathrm{mAh} \mathrm{g}^{-}$ ${ }^{1}$. Discharge capacity retained at $\sim 1020 \mathrm{mAh} \mathrm{g}^{-1}$ after 100 cycles. (86\%) The highest fading belongs to uncoated glass fiber separator with initial capacity of $1600 \mathrm{mAh} \mathrm{g}^{-1}$ and capacity retention of $\sim 500 \mathrm{mAh} \mathrm{g}^{-1}$. (31\%)

As shown in Figure 5, the cell with uncoated separator had lowest Coulombic efficiency of $\sim 90$ $\%$, indicating deterioration of the electrochemical reversibility and facil diffusion of polysulfide toward the anode. High fading rate and low Coulombic efficiency for uncoated glass fiber separator indicates the role of coatings to restrain polysulfide diffusion and parasitic reactions. In contrast, the cells with PDAAQ/L-GO and $\mathrm{SiO}_{2} / \mathrm{L}-\mathrm{GO}$ coated separators showed high Coulombic efficiencies of $97-100 \%$. The cell with the separator coated with $\mathrm{TiO}_{2} / \mathrm{L}-\mathrm{GO}$ delivered the Coulombic efficiency of 95-98\%. 


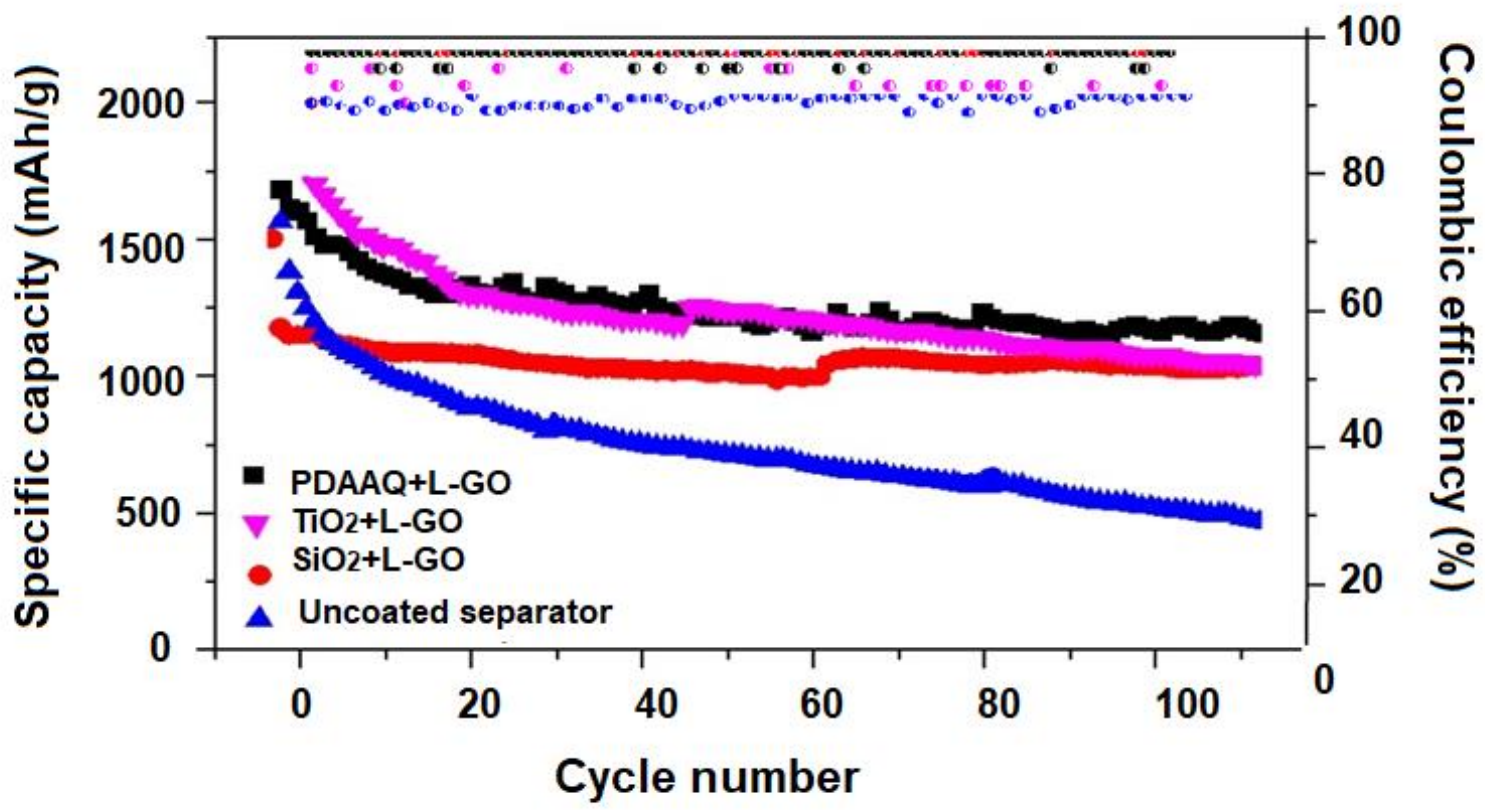

Figure 5. Coulombic efficiency and cycle performance for the cells with the bare and coated separator at $1 \mathrm{C}$.

Figure 6 shows a typical charge-discharge voltage profile with two discharge plateaus at $\sim 2.4$ and $\sim 2.0 \mathrm{~V}$ with the cells with three different coatings. For the cells with PDAAQ/L-GO and $\mathrm{TiO}_{2} / \mathrm{L}-\mathrm{GO}$ coatings charge curve declines to $1.5 \mathrm{~V}$ up to $200 \mathrm{mAh} \mathrm{g}^{-1}$ and then increases to 2.4 and $2.8 \mathrm{~V}$ with two charge plateaus curve respectively. The cell with $\mathrm{SiO}_{2} / \mathrm{L}-\mathrm{GO}$ coating demonstrated two discharge plateaus correspond to conversion of sulfur (S8) to long chain $\left(\mathrm{Li}_{2} \mathrm{~S}_{\mathrm{n}}, 4 \leq \mathrm{n} \leq 8\right)$ and short chain lithium polysulfides ( $\mathrm{Li}_{2} \mathrm{~S}_{2}$ and $\left.\mathrm{Li}_{2} \mathrm{~S}\right)$, and the two plateaus in the charge process correspond to the reverse reactions from short chain polysulfides $\left(\mathrm{Li}_{2} \mathrm{~S}_{2}\right.$ and $\left.\mathrm{Li}_{2} \mathrm{~S}\right)$ to long chain polysulfides $\left(\mathrm{Li}_{2} \mathrm{~S}_{\mathrm{n}}, 4 \leq \mathrm{n} \leq 8\right)$ and finally to sulfur (S8). A small plateau near $2.1 \mathrm{~V}$ was observed in the cell with $\mathrm{SiO}_{2} / \mathrm{L}-\mathrm{GO}$ and PDAAQ/L-GO coatings after 10, 20 and 60 cycles, represented the formation of a discrete phase or imperfection in the $\mathrm{SiO}_{2}$ or PDAAQ structure [56-58]. In addition, a lower polarization in the charge-discharge profiles of the cell with 
PDAAQ/L-GO coated separator indicates high ability of PDAAQ for polysulfide trapping and electrolyte retention. The cell with $\mathrm{SiO}_{2} / \mathrm{L}-\mathrm{GO}$ coating could keep polarization potential constant even after 60 cycle. Due to hydrophilicity and electrolyte retention property of L-GO, satisfactory capacities of 1005, 800 and $910 \mathrm{mAh} \mathrm{g}^{-1}$ delivered for the cells with PDAAQ/L-GO, $\mathrm{SiO}_{2} / \mathrm{L}-\mathrm{GO}$ and $\mathrm{TiO}_{2} / \mathrm{L}-\mathrm{GO}$ after 60 cycles at $2 \mathrm{C}$.
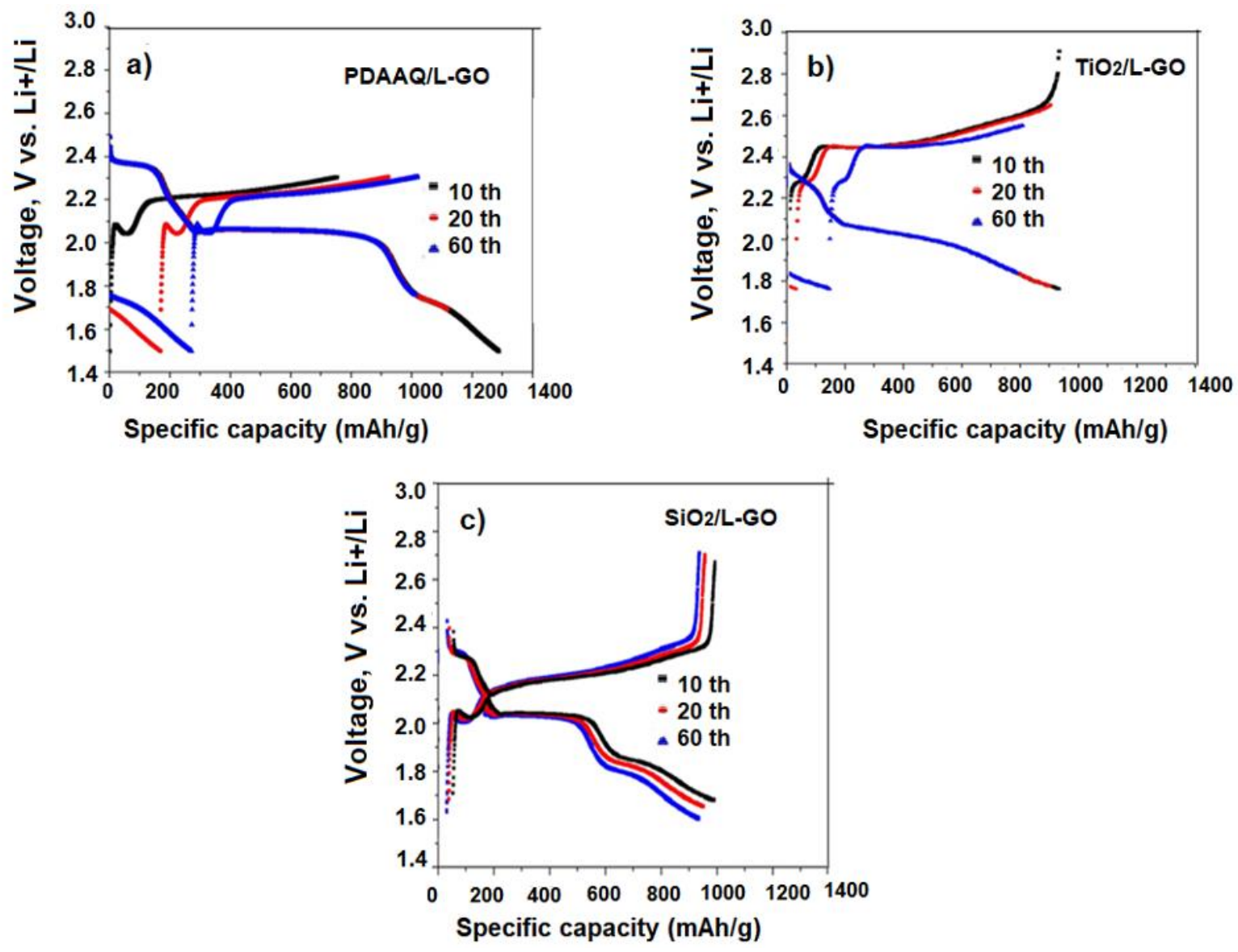

Figure 6. The charge-discharge voltage profiles for the Li-S cells with the a) PDAAQ/L-GO b) $\mathrm{TiO}_{2} / \mathrm{L}-\mathrm{GO}$ c) $\mathrm{SiO}_{2} / \mathrm{L}-\mathrm{GO}$ coatings on glass fiber separator at $2 \mathrm{C}$.

As shown in Figure 7, the cell with PDAAQ/L-GO coated separator delivered highest rate performance with a discharge specific capacity of $\sim 1500 \mathrm{mAh} \mathrm{g}^{-1}$ at $1 \mathrm{C}$. When the current 
density increased to 2 and 5C, the corresponding discharge capacities were $\sim 1250$ and 1000 $\mathrm{mAh} \mathrm{g}^{-1}$, respectively. The discharge capacity is recovered at $\sim 1200$ and $1250 \mathrm{mAh} \mathrm{g}^{-1}$ when the current densities were turned back to 2 and $1 \mathrm{C}$. The cell with $\mathrm{TiO}_{2} / \mathrm{L}-\mathrm{GO}$ coated separator delivered discharge specific capacity of $\sim 1350 \mathrm{mAh} \mathrm{g}^{-1}$ at $1 \mathrm{C}$, but, as the current density increased to 2 and 5C, the discharge specific capacities were decreased to $\sim 1000$ and $780 \mathrm{mAh} \mathrm{g}^{-}$ ${ }^{1}$, respectively. The cell with $\mathrm{SiO}_{2} / \mathrm{L}-\mathrm{GO}$ coated separators demonstrated poor rate performance with discharge capacities of $\sim 1100,770,580,750$ and $800 \mathrm{mAh} \mathrm{g}^{-1}$ at 1, 2, 5, 2 and 1C, respectively.

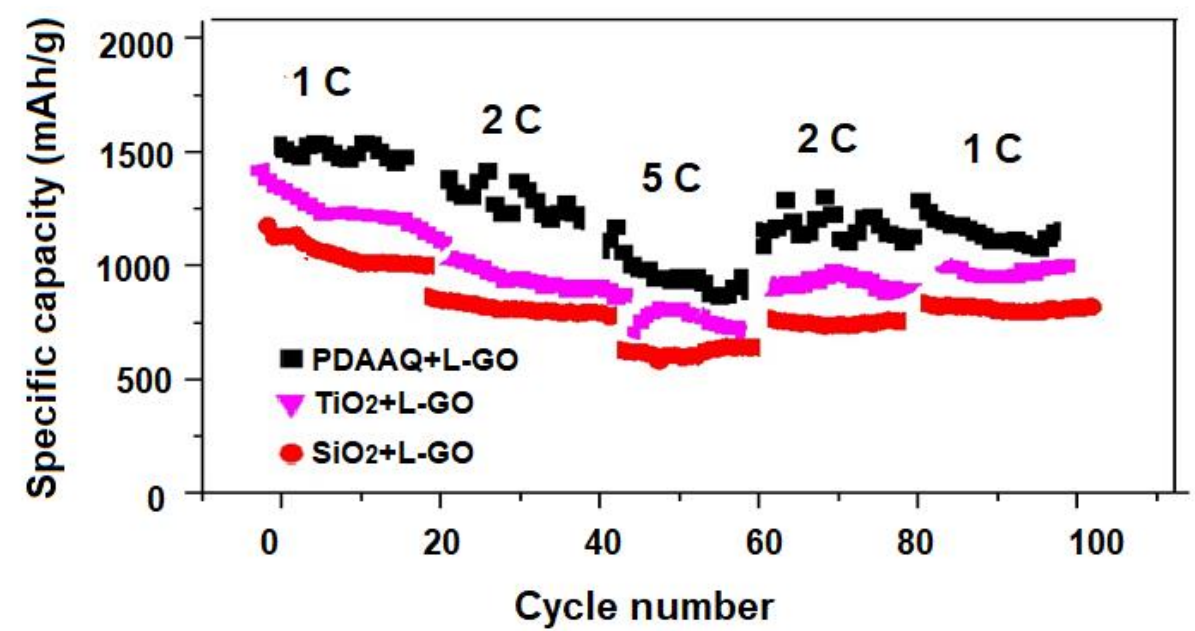

Figure 7. The rate capability of the Li-S cells with the different separators.

The electrochemical impedance spectrum was investigated for the cells with three different coatings (Figure 8). The equivalent circuits represent several elements including Re is the resistance of the electrolyte, Rct is the charge transfer resistance, R1 is the deposit diffusion resistance of short chain polysulfide, $\mathrm{CPE} 1$ is constant phase elements, and $\mathrm{Zw}$ is the Warburg diffusion impedance of the polysulfide. The impedance spectra for all three cells showed two depressed semicircle and inclined line (Warburg impedance). The depressed semicircle indicates 
the formation of short chain lithium-polysulfide while the straight inclined line associates with the diffusion of lithium ions within the cathode materials [59-62].

All impedance test was investigated after 1 cycle, all three cells showed reduced charge transfer resistance values, but the cell with PDAAQ/L-GO coated separator delivered a lowest resistance compared to others (Figure 8). The charge transfer resistance (Rct) of the batteries using $\mathrm{SiO}_{2} / \mathrm{L}-$ GO, $\mathrm{TiO}_{2} / \mathrm{L}-\mathrm{GO}$ and PDAAQ/L-GO coatings on glass fiber separators was 22.3, 23.6 and 18.9 $\Omega$, respectively, indicated that the application of PDAAQ can effectively reduce the charge transfer resistance. All impedance plots are consisted of a semicircle in the high frequency and a slant line in the low frequency. The cell with PDAAQ separator demonstrate smaller semicircle than the $\mathrm{TiO}_{2}$ and $\mathrm{SiO}_{2}$ separator, indicating that the PDAAQ/L-GO coatings provides better electrochemical performance with higher reversible capacity.

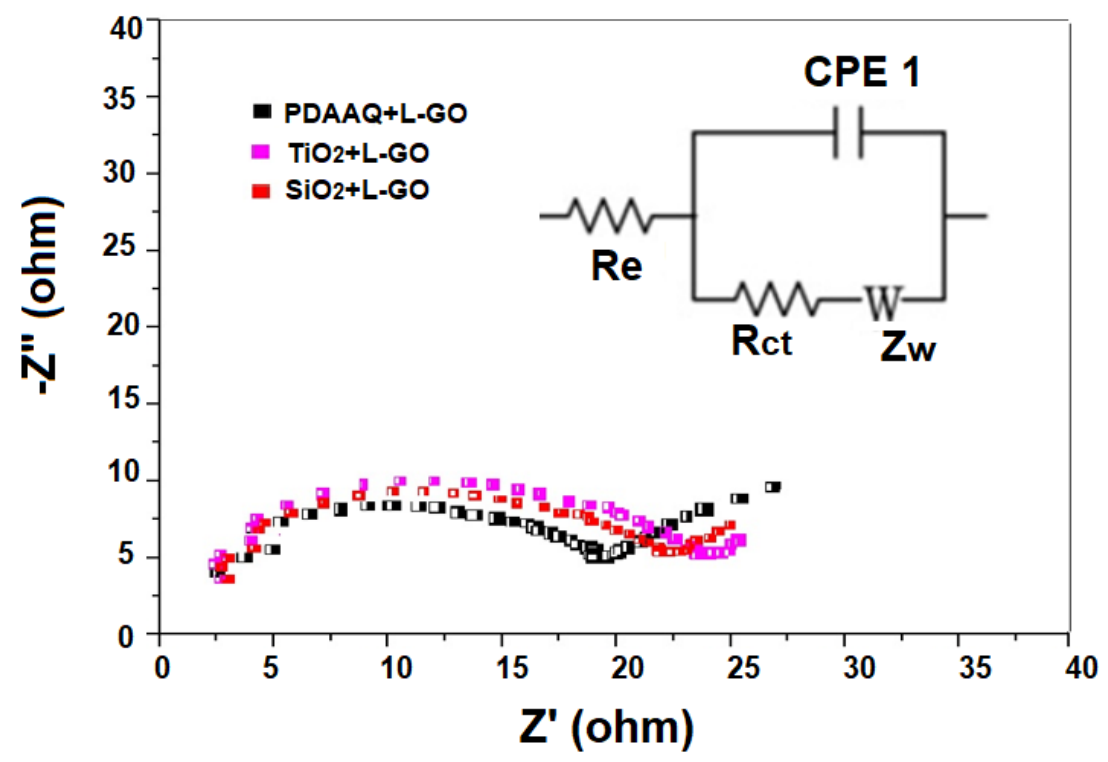

Figure 8. Electrochemical impedance spectroscopy for $\mathrm{Li}-\mathrm{S}$ cells with $\mathrm{SiO}_{2} / \mathrm{L}-\mathrm{GO}, \mathrm{TiO}_{2} / \mathrm{L}-\mathrm{GO}$ and PDAAQ/L-GO coatings on glass fiber separators after first charge discharge cycle. 
Figure 9 shows $\mathrm{CV}$ curves of $\mathrm{Li}-\mathrm{S}$ cells with $\mathrm{SiO}_{2}, \mathrm{TiO}_{2}$ and $\mathrm{PDAAQ}$ with $\mathrm{L}-\mathrm{GO}$ binder coated separators vs. $\mathrm{Li}+/ \mathrm{Li}$. The $\mathrm{CV}$ curves for the cells with the three different coated separators were almost identical. The two reduction peaks in the cathodic scan for the cells with $\mathrm{SiO}_{2} / \mathrm{L}-\mathrm{GO}$, $\mathrm{TiO}_{2} / \mathrm{L}-\mathrm{GO}$ and PDAAQ/L-GO coated separators was observed. First cathodic peaks for the cells with $\mathrm{SiO}_{2} / \mathrm{L}-\mathrm{GO}, \mathrm{TiO}_{2} / \mathrm{L}-\mathrm{GO}$ and PDAAQ/L-GO coated separators were at $\sim 1.97,2.0$ and 2.02 $\mathrm{V}$ respectively corresponding to the reduction of elemental sulfur (S8) to the high-order polysulfide $\left(\mathrm{Li}_{2} \mathrm{~S}_{\mathrm{n}}, 4 \leq \mathrm{n} \leq 8\right)$ and the second cathodic peaks for the cells with $\mathrm{SiO}_{2} / \mathrm{L}-\mathrm{GO}, \mathrm{TiO}_{2} / \mathrm{L}-$ GO and PDAAQ/L-GO coated separators were at $\sim 2.3,2.41$ and $2.41 \mathrm{~V}$ respectively corresponding to the reduction of long chain polysulfide to short chain polysulfide (insoluble $\mathrm{Li}_{2} \mathrm{~S}_{2}$ and $\left.\mathrm{Li}_{2} \mathrm{~S}\right)$. The decreased polarization of cell with PDAAQ/L-GO, indicated that the addition of PDAAQ improved redox kinetics. Compared to $\mathrm{SiO}_{2} / \mathrm{L}-\mathrm{GO}$ and $\mathrm{TiO}_{2} / \mathrm{L}-\mathrm{GO}$, the PDAAQ/L-GO display a smaller electrochemical polarization with more positive reduction peaks and negative oxidation peaks, which is in good agreement with accelerated redox kinetics by PDAAQ. PDAAQ provides strong adsorption ability to trap soluble lithium polysulfides, which can effectively facilitate the $\mathrm{Li}+/ \mathrm{e}^{-}$diffusion transfer subsequently promote the conversion of short chain lithium polysulfides to long chain polysulfides. Additionally, PDAAQ with abundant polar sites helps speed up the conversions between soluble long chain polysulfides and solid short chain polysulfides during cycling.

A broad oxidation anodic peaks which is associated with conversion of short chain polysulfide $\left(\mathrm{Li}_{2} \mathrm{~S}_{2}\right.$ and $\left.\mathrm{Li}_{2} \mathrm{~S}\right)$ to long chain polysulfide $\left(\mathrm{Li}_{2} \mathrm{~S}_{\mathrm{n}}, 4 \leq \mathrm{n} \leq 8\right)$ and elemental sulfur emerged in the range of $\sim 2.65$ to 2.80 for the cells with $\mathrm{SiO}_{2} / \mathrm{L}-\mathrm{GO}, \mathrm{TiO}_{2} / \mathrm{L}-\mathrm{GO}$ and $\mathrm{PDAAQ} / \mathrm{L}-\mathrm{GO}$ coated separators. The sharp peaks with expected reduction and oxidation peak positions in the CV 
curves for the cells with three different coatings on the separator illustrates electrochemical stability of the coatings within the $1.5-3 \mathrm{~V}$.

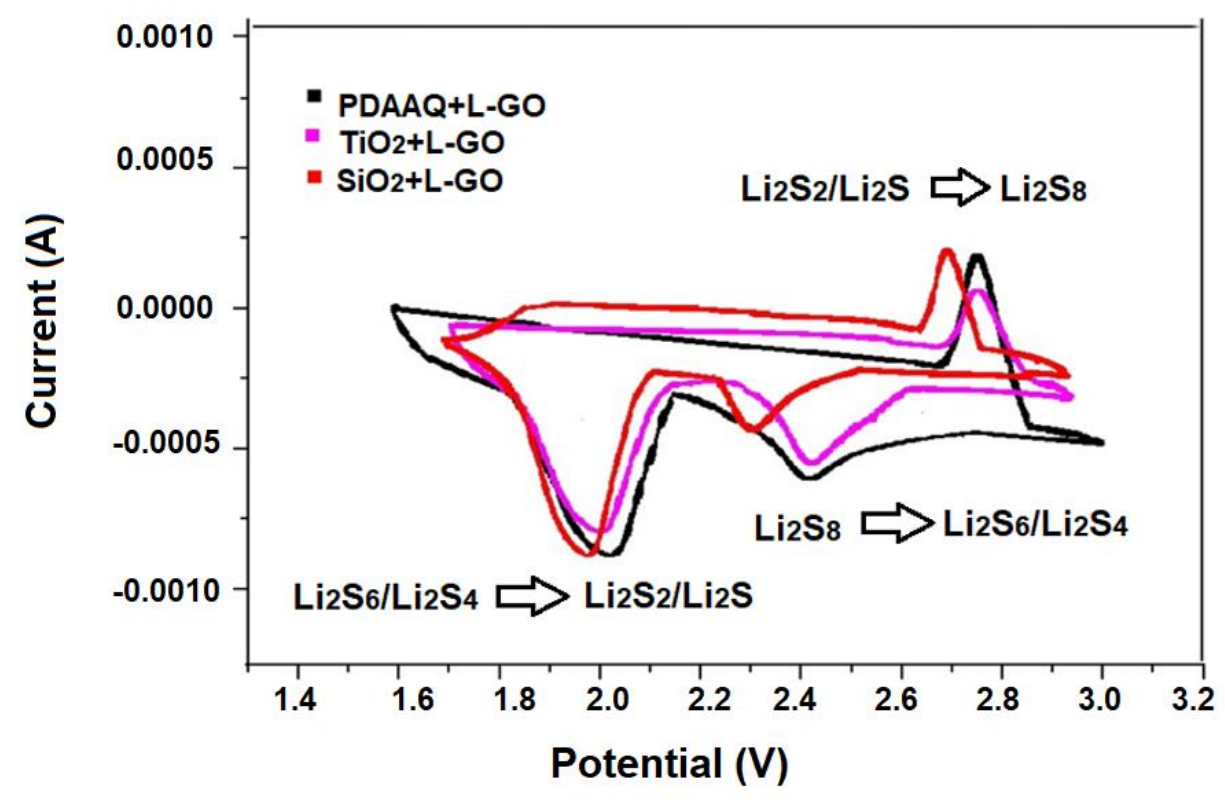

Figure 9. CV curves for the cells with three different coatings at the scanning rate of $0.1 \mathrm{mV} \mathrm{s}^{-1}$.

\section{Conclusions}

In summary, highly porous structure of the glass fiber separator contributes to enhance the adsorption of polysulfide intermediates and reduce the rapid diffusion of polysulfides to the anode. The $\mathrm{Li} / \mathrm{S}$ cell, using glass fiber separator coating with $\mathrm{SiO}_{2}, \mathrm{TiO}_{2}$ or PDAAQ can form chemical binding and also physically adsorb the lithium polysulfides through these novel coatings, alleviating the shuttle effect. Additionally we demonstrated that modification of the glass fiber separator with $\mathrm{SiO}_{2}, \mathrm{TiO}_{2}$ and PDAAQ coatings with novel L-GO binder has strongly improved the chemical and electrochemical properties of the coated separators, as well as the performance of the Li-S cell. 
$\mathrm{SiO}_{2}, \mathrm{TiO}_{2}$ and PDAAQ coatings with L-GO binder on the glass fiber separator could trap polysulfides through physical and chemical confinement of polysulfides. Among them, PDAAQ could adsorb more polysulfides on the surface of glass fiber separator due to redox-assisted hydrogen bonding of quinone groups in PDAAQ, simultaneously increasing the specific capacity. Due to hydrophilicity and electrolyte retention property of L-GO, satisfactory capacities of 1005, 800 and $910 \mathrm{mAh} \mathrm{g}^{-1}$ delivered for the cells with PDAAQ/L-GO, $\mathrm{SiO}_{2} / \mathrm{L}-\mathrm{GO}$ and $\mathrm{TiO}_{2} / \mathrm{L}-\mathrm{GO}$ after 60 cycles at $2 \mathrm{C}$. This work demonstrates that application of novel L-GO binder and surface modification of the glass fiber separators presents a promising way for improving performance of the Li-S cell.

\section{References}

[1] Yang Z, Zhang J, Kintner-Meyer M C, Lu X, Choi D, Lemmon J P and Liu J 2011 Chem. Rev. 111 3577

[2] Goodenough J B and Kim Y 2010 Chem. Mater. 22587

[3] Urbonaite S, Poux T and Novák P 2015 Adv. Energy Mater. 51500118

[4] Li G, Wang S, Zhang Y, Li M, Chen Z and Lu J 2018 Adv. Mater. 301705590

[5] Diao Y, Xie K, Xiong S and Hong X 2013 J. Power Sources 235181

[6] Yan J, Liu X and Li B 2016 Adv. Sci. 31600101

[7] Xie Y, Meng Z, Cai T and Han W Q 2015 ACS. Appl. Mater. 725202

[8] Qiu Y, Li W, Zhao W, Li G, Hou Y, Liu M, Zhou L, Ye F, Li H, Wei Z and Yang S 2014 Nano Lett. 144821

[9] Zhou G, Paek E, Hwang G S and Manthiram A 2015 Nat. Commun. 67760

[10] Gu X, Tong C J, Lai C, Qiu J, Huang X, Yang W, Wen B, Liu L M, Hou Y and Zhang S 2015 J. Mater. Chem. A 316670

[11] Pang Q, Kundu D, Cuisinier M and Nazar L F 2014 Nat. Commun. 54759

[12] Zhang S, Ueno K, Dokko K and Watanabe M 2015 Adv. Energy Mater. 51500117

[13] Ji L, Rao M, Aloni S, Wang L, Cairns E J and Zhang Y 2011 Energy. Environ. Sci. 45053

[14] Su Y S and Manthiram A 2012 Chem. Commun. 488817

[15] Kaewruang S, Chiochan P, Phattharasupakun N, Suktha P, Kongpatpanich K, Maihom T, Limtrakul J and Sawangphruk M 2017 Carbon 123492 
[16] Liu Y, Shen S, Zhang J, Zhong W and Huang X 2019 Appl Surf Sci. 478762

[17] Zhong W, Shen S, Feng S, Lin Z, Wang Z and Fang B 2018 Cryst. Eng. Comm. 207851

[18] ] Zhong W, Tu W, Feng S and Xu A 2019 J. Alloys. Compd. 772669

[19] Zhu J, Yanilmaz M, Fu K, Chen C, Lu Y, Ge Y, Kim D and Zhang X 2016 J. Membr. Sci. 50489

[20] Jayaprakash N, Shen J, Moganty S S, Corona A andArcher L A 2011 Angew. Chem. Int. Ed. 505904

[21] Liang C, Dudney N J and Howe J Y 2009 Chem. Mater. 214724

[22] Zheng G, Yang Y, Cha J J, Hong S S and Cui Y 2011 Nano Lett. 114462

[23] Fu K, Li Y, Dirican M, Chen C, Lu Y, Zhu J and Zhang X 2014 Chem. Commun. 5010277

[24] Huang J Q, Zhang Q, Zhang S M, Liu X F, Zhu W, Qian W Z and Wei F 2013 Carbon 5899

[25] Wang Z, Dong Y, Li H, Zhao Z, Wu H B, Hao C and Lou X D W 2014 Nat. Commun. 51

[26] Huang J Q, Liu X F, Zhang Q, Chen C M, Zhao M Q, Zhang S M, Wei F 2013 Nano. Energy 2314

[27] Li Y, Cai Q, Wang L, Li Q, Peng X, Gao B, Huo K and Chu P K 2016 ACS. Appl. Mater. 823784

[28] Yang Y, Yu G, Cha J J, Wu H, Vosgueritchian M, Yao Y and Cui Y 2011 ACS Nano. 59187

[29] Zhou G, Pei S, Li L, Wang D W, Wang S, Huang K and Cheng H M 2014 Adv. Mater. 26625

[30] Huang J Q, Zhuang T Z, Zhang Q, Peng H J, Chen C M and Wei F 2015 ACS Nano. 93002

[31] Deng N, Feng Y, Wang G, Wang X, Wang L, Li Q, Zhang L, Kang W, Cheng B and Liu 2020

Chem. Eng. 23125976

[32] Song M S, Han S C, Kim H S, Kim J H, Kim K T, Kang Y M and Lee J Y 2004 J. Electrochem. Soc. 151 A791

[33] Choi Y J, Jung B S, Lee D J, Jeong J H, Kim K W, Ahn H J and Gu H B 2007 Phys.Scr. 200762

[34] Evers S, Yim T and Nazar L F 2012 J. Phys. Chem. C 11619653

[35] Pang Q, Kundu D, Cuisinier M and Nazar L F 2014 Nat. Commun. 54759

[36] Tao X, Wang J, Ying Z, Cai Q, Zheng G, Gan Y and Cui Y 2014 Nano Lett. 145288

[37] Liang X, Hart C, Pang Q, Garsuch A, Weiss T and Nazar L F 2015 Nat. Commun. 61

[38] Trevey J E,. Stoldt C R and Lee S H 2011 J. Electrochem. Soc. 158 A1282

[39] Kiai M S, Eroglu O and Kizil H 2020 J. Appl. Polymer Sci. 13748606

[40] Ma X Z, Jin B, Wang H Y, Hou J Z, Zhong X B, Wang H H and Xin P M 2015 J. Electroanal.

Chem. 736127

[41] Shao H Y, Wang W K, Zhang H, Wang A B, Chen X N and Huang Y Q 2018 J. Power Sources 378 537

[42] Shan L, Yurong C, Jing Y, Feixia R, Jun W, Babu S, Xin Y, Junkuo G and Juming Y 2019 J. Alloys. Compd. 779412

[43] Liu X, Huang J Q, Zhang Q and Mai L Q 2017 Adv. Mater. 291601759

[44] Noël V and Randriamahazaka H N 2012 Electrochem.commun. 1932 
[45] Chen G, Li J, Liu N, Zhao Y, Tao J, Kalimuldina G, Bakenov Z and Zhang Y 2019 Electrochim. Acta 326134968

[46] Siburian R, Sihotang H, Raja S L, Supeno M and Simanjuntak C 2018 Orient. J. Chem. 34182

[47] Nandanwar R, Singh P and Haque F Z 2015 Int. J. Chem 1-10

[48] Zheng J, Liu Z, Liu X, Yan X, Li D and Chu W 2011 J. Alloys. Compd. 5093771

[49] Eroglu O, Kiai M S, Kizil H 2020 J. Alloys. Compd. 155607

[50] Aghaei R and Eshaghi A 2017 J. Alloys. Compd. 699112

[51] Peng H, Ma G, Sun K, Mu J, Zhou X and Lei Z 2015 Rsc Adv. 512034

[52] Li N, Wang Z, Zhao K, Shi Z, Gu Z and Xu S 2010 Carbon 48255

[53] Lee D K, Ahn C W and Jeon H J 2017 J. Power Sources 360559

[54] Eshaghi A and Eshaghi A 2012 App. Surf. Sci. 2582464

[55] Eroglu O, Kiai M S and Kizil H 2020 Mate.Res. Bull. 110917

[56] Peng H, Wang X, Zhao Y, Tan T, Mentbayeva A, Bakenov Z and Zhang Y 2017 J. Nanopart. Res. 19348

[57] Gao X, Zhu H, Pan G, Ye S, Lan Y, Wu F and Song D 2004 J. Phys. Chem. B 1082868

[58] Yin L, Xu G, Nie P, Dou H and Zhang X 2018 Chem. Eng. J. 352695

[59] Lu S, Cheng Y, Wu X and Liu J 2013 Nano let. 132485

[60] Yuan L, Qiu X, Chen L and Zhu W 2009 J. Power Sources 189127

[61] Deng Z, Zhang Z, Lai Y, Liu J, Li J and Liu Y 2013 J. Electrochem. Soc. 160 A553

[62] Cañas N A, Hirose K, Pascucci B, Wagner N, Friedrich K A and Hiesgen R 2013 Electrochim. Acta. 9742

[63] Barchasz C, Molton F, Duboc C, Leprêtre J C, Patoux S and Alloin F 2012 Analytical chem. 843973 